\title{
Hypopharyngeal Cancer pT1 TNM Finding v6
}

National Cancer Institute

\section{Source}

National Cancer Institute. Hypopharyngeal Cancer pT 1 TNM Finding v6. NCI Thesaurus. Code C64449.

Hypopharyngeal cancer with tumor limited to one subsite of the hypopharynx and with tumor size 2 centimeters or less in greatest dimension. (from AJCC 6th Ed.) 